\title{
FRESHWATER ICHTHYOFAUNA IN THE MULLEGAMA-HABARAKADA AREA, COLOMBO DISTRICT, SRI LANKA
}

\author{
B.S.A.T. Hiranya Sudasinghe ${ }^{1}$, P.W.D. Thisara Nilupul ${ }^{2}$ \& Sudeera P.J Bandara ${ }^{3}$ \\ 1,2,3 Young Zoologists' Association, Department of National Zoological Gardens, Dehiwala, Sri Lanka \\ ${ }^{1}$ hsudasinghe@gmail.com (Corresponding author), ${ }^{2}$ vithanage.thisara@gmail.com, ${ }^{3}$ sudbanarenga@gmail.com
}

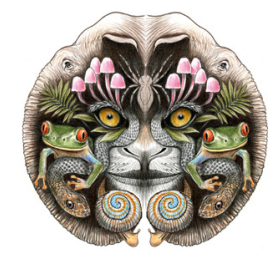

ISSN

Online 0974-7907 Print 0974-7893

OPEN ACCESS

\begin{abstract}
The diversity of fishes in a small stream in the MullegamaHabarakada area of Sri Lanka was studied. A total of 16 species belonging to nine families were recorded, of which three are endemic and two are exotic to the country. The threats to the area include habitat degradation as a result of release of waste water, unmanaged waste disposal, sand mining and algal blooms. The abundance of Cherry Barb Puntius titteya was very low during the study period. This species is likely to be extirpated from Habarakada, unless urgent conservation measures are taken.
\end{abstract}

Keywords: Conservation, fish, Puntius titteya, threats

Sri Lanka has a high diversity of vertebrate fauna (IUCN Sri Lanka \& MENR 2007), including 93 native freshwater fishes (53 endemics) (MoE 2012; Batuwita et al. 2013). Of these, 21 are listed as Critically Endangered, 19 as Endangered and five as Vulnerable in the National Red List (MoE 2012). In addition, 24 exotic species have been introduced to the island, mainly to boost aquaculture and inland capture fisheries (Goonatilake 2007).

Habitat degradation is the major threat affecting the survival of Sri Lanka's freshwater fishes (Senanayake \& Moyle 1982). For example, in Colombo District, increased urbanization has resulted in the decline of natural fish habitats. Thirty-three species of freshwater fish were recorded at the Bellanwila-Attidiya Sanctuary during
1980 to 1988 which is located close to the suburbs of Colombo (Nalinda 1988), while this number decreased to 22 species in 2005-2006 (Karunarathna et al. 2010) and to a mere eight species in 2012 (Goonatilake 2012). Kotalawala (1994) recorded 28 species from Wak Oya, a tributary of the Kelani River on the outskirts of Colombo. The outskirts of Colombo still provide important habitats for the persistence of native freshwater fishes with $\sim 40+$ species having high endemism (Hiranya Sudasinghe, pers. obs. 2013). Therefore, conserving these last remaining habitats is vital to ensuring the survival of freshwater fishes.

The main threats to the native fish fauna in Colombo District include water pollution, habitat loss, destruction of aquatic vegetation and exotic species (Karunarathna et al. 2010) together with deforestation, urbanization, gem mining, toxic spills and weirs (Kotalawala 1994).

The Cherry Barb Puntius titteya is an Endangered (MoE 2012) and endemic cyprinid which prefers heavily shaded streams in the lowland wet zone of the country. It is distributed from Kelani to Nilwala (Pethiyagoda 1991) and in Walawe basins (Batuwita et al. 2013). The status of $P$. titteya in the district of Colombo is however not clearly understood. Deraniyagala (1929) in his description of $P$. titteya recorded it from Wye

DOI: http://dx.doi.org/10.11609/JoTT.03583.5731-7 | ZooBank: urn:Isid:zoobank.org:pub:D61C2564-D938-4E16-B476-3BE1D0497B5B

Editor: Rajeev Raghavan, Conservation Research Group (CRG), St. Albert's College, Kochi, India.

Date of publication: 26 May 2014 (online \& print)

Manuscript details: Ms \# 03583 | Received 11 April 2013 | Final received 12 May 2014 | Finally accepted 13 May 2014

Citation: Sudasinghe, B.S.A.T.H., P.W.D.T. Nilupul \& S.P.J Bandara (2014). Freshwater ichthyofauna in the Mullegama-Habarakada area, Colombo District, Sri Lanka. Journal of Threatened Taxa 6(5): 5731-5737; http://dx.doi.org/10.11609/JoTT.03583.5731-7

Copyright: (C) Sudasinghe et al. 2014. Creative Commons Attribution 4.0 International License. JoTT allows unrestricted use of this article in any medium, reproduction and distribution by providing adequate credit to the authors and the source of publication.

Funding: Self funded.

Competing Interest: The authors declare no competing interests.

Acknowledgements: The authors wish to thank Dr. Thilina Surasinghe (Clemson University - USA) and the anonymous reviewers for their invaluable comments in preparing the manuscript. The first author is grateful to Mr. Shantha Jayaweera, Mr. Bandula Jayanetthi, Mr. Jagath Gunawardane, Mr. Sameera Suranjan Karunaratna (NEET/YZA), Miss Iresha Harischandra (YZA), Mr. Hasantha Wijethunga(YZA), Mr. Asela Weerawardane and Mrs. Gayani Ranawake for their advice, encouragement and support. 
Estate, Homagama which is close to Habarakada, on the outskirts of Colombo. Puntius titteya is still observed in small shady streams on the outskirts of Colombo District (Hiranya Sudasinghe, pers. obs. 2013). This study was conducted in Habarakada to understand the diversity of fish species and assess the status of, and threats affecting $P$. titteya and their habitats.

\section{Materials and Methods}

Study area: Mullegama-Habarakada area is located in Colombo District of the wet zone of Sri Lanka approximately $4 \mathrm{~km}$ from Godagama Town (Fig. 1). The study was conducted at a small stream flowing inbetween a paddy field and an area of human habitation. The study site is located at a distance of about $100 \mathrm{~m}$ from the Meegoda-Athurugiriya Road (B240). Land use pattern in this region consists of paddy fields and residential areas. The stream flows along the side of the paddy fields for about $360 \mathrm{~m}$ and then connects to a main canal running through the paddy fields. The closest major river to the study site is the Kelani River. Brief descriptions of the sampling sites are given in Table 1.

Fish Sampling: Our sampling sites consisted of habitats that differed in canopy shade, stream substrate, relative visibility, marginal vegetation, surrounding, as well as type and intensity of human disturbances. Four such different habitats were selected along the stream and were named as Plot A, B, C and D (Images $1 \mathrm{a}-\mathrm{e}$ ). Though the survey was started in the month of December 2009, field visits were carried out prior to the survey, beginning August 2009. Field visits were made twice a month for a period of one year from December 2009 to December 2010. Two night visits were organized in order to observe the nocturnal species. The fishes were caught using a hand net $(60 \times 30 \mathrm{~cm})$, transferred to a glass tank, identified and released back to their habitat. Snorkeling was done at Plot $\mathrm{C}$ in order to observe the behavior of a few species. The species were identified following Pethiyagoda (1991), Goonatilake (2007) \& Silva et al. (2010).

\section{Results}

A total of 16 fish species belonging to nine families (Table 2) were recorded during the study, i.e., $13.67 \%$ of the overall freshwater fish diversity of Sri Lanka. This includes three endemic and two exotic species. The three endemic species recorded during the study were Smooth-breasted Snakehead Channa orientalis, Horadandia Horadandia atukorali and Cherry

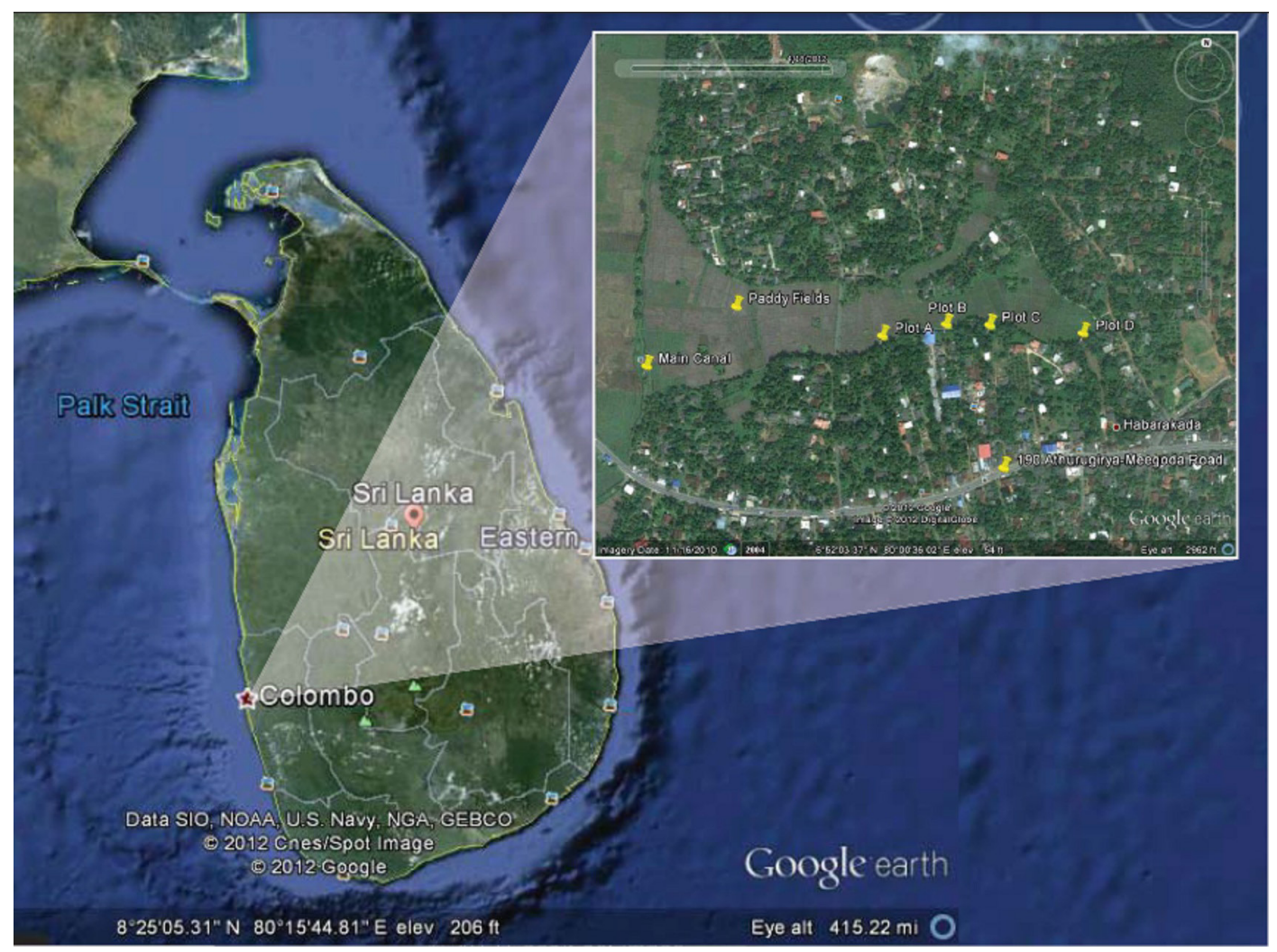

Figure 1. Map of Sri Lanka showing the study area 
Table 1. Description of the sampling sites

\begin{tabular}{|c|l|l|l|l|l|}
\hline $\begin{array}{c}\text { Sampling } \\
\text { site }\end{array}$ & $\begin{array}{c}\text { Canopy } \\
\text { shade }\end{array}$ & Marginal vegetation & $\begin{array}{l}\text { Relative visibility of } \\
\text { stream }\end{array}$ & Stream substrate & Surrounding land use \\
\hline A & $60-70 \%$ & $\begin{array}{l}\text { Heavily margined by shrubs and } \\
\text { bushes and ferns with few trees. }\end{array}$ & Clear, bottom visible & $\begin{array}{l}\text { Mainly muddy with leaf debris } \\
\text { and few pebbles }\end{array}$ & $\begin{array}{l}\text { Paddy fields on one side and } \\
\text { other side consists of a sparsely } \\
\text { wooded undeveloped land }\end{array}$ \\
\hline B & Open; $0 \%$ & Weeds and grasses & Clear, bottom visible & Mud, sandy & $\begin{array}{l}\text { Human settlements and paddy } \\
\text { fields }\end{array}$ \\
\hline C & $90-100 \%$ & $\begin{array}{l}\text { Heavily margined by shrubs and } \\
\text { bushes with ferns and trees. }\end{array}$ & Clear, bottom visible & $\begin{array}{l}\text { Mainly leaf debris. Other than } \\
\text { that sand and clay }\end{array}$ & $\begin{array}{l}\text { Surrounded by several large } \\
\text { trees and bushes. }\end{array}$ \\
\hline D & $80-90 \%$ & $\begin{array}{l}\text { Weeds, grasses and few ferns } \\
\text { and trees. }\end{array}$ & Clear, bottom visible & $\begin{array}{l}\text { Mainly sandy followed by few } \\
\text { leaf debris and mud. }\end{array}$ & $\begin{array}{l}\text { Human settlements and paddy } \\
\text { fields }\end{array}$ \\
\hline
\end{tabular}

Table 2. Checklist of freshwater fish recorded from the four sampling sites.

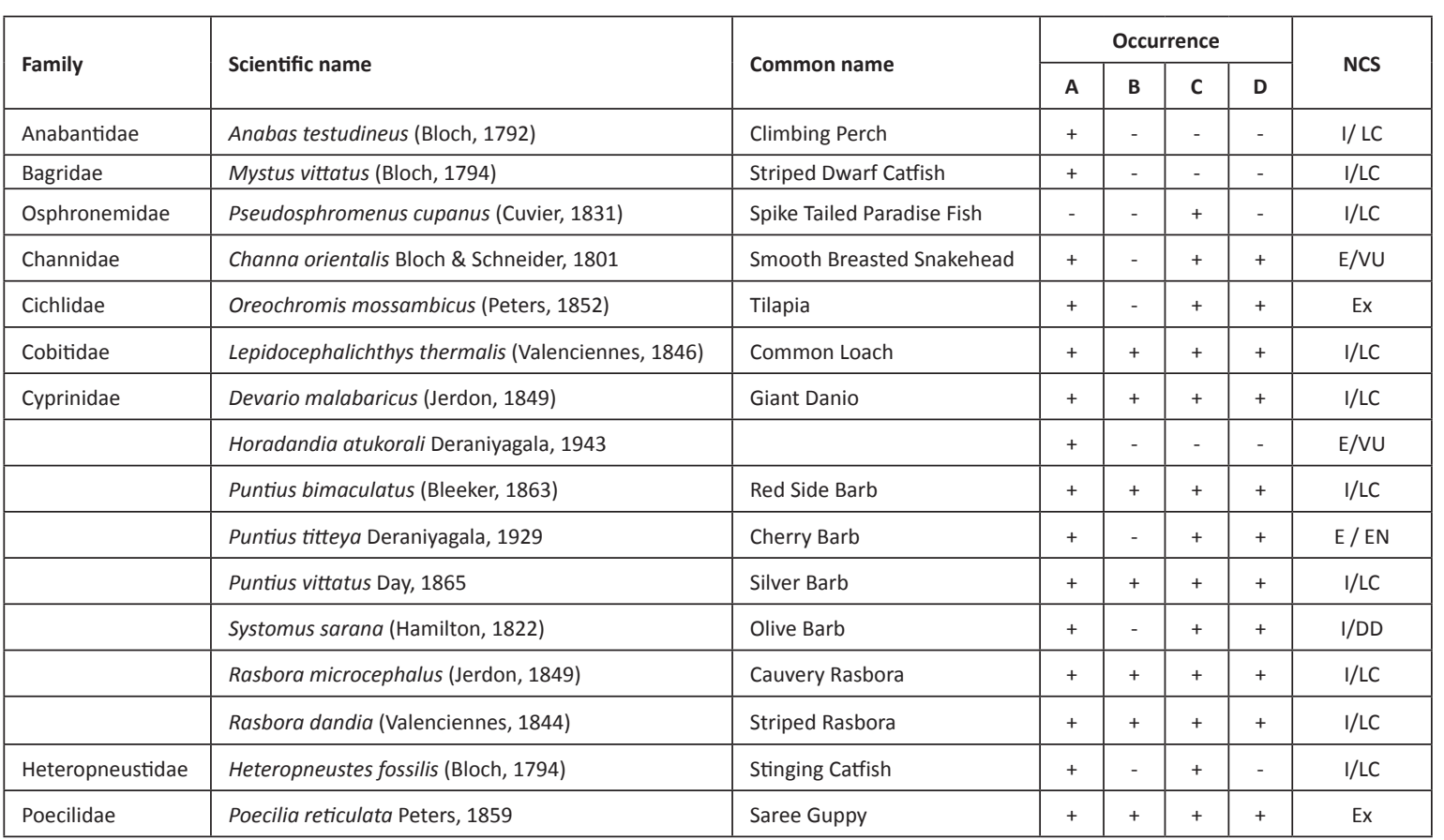

+ - Present; - - Absent; NCS - National Conservation Status (National Red List, MoE 2012); I - Indigenous; E - Endemic; Ex - Exotic; EN - Endangered; VU - Vulnerable; LC - Least Concern; DD - Data Deficient).

Barb Puntius titteya. The two exotic species were Mozambique Tilapia Oreochromis mossambicus and Guppy Poecilia reticulata. Family Cyprinidae dominated the fauna with eight species, i.e., 50\% from the total number. All the other families were represented by a single species. Rasbora dandia (Image 2f), Puntius bimaculatus and Devario malabaricus (Image 2e) were the most abundant species inhabiting all the four habitats. Channa orientalis and Heteropneustes fossilis were the predatory fishes recorded from the stream. Of these two, $C$. orientalis was found in higher abundance than $H$. fossilis. The occurrence of each species in the four sampling sites is given in Table 2.
Plot A had the highest, and Plot B had the lowest species richness. Anabas testudineus, Mystus vittatus, $H$. fossilis and $S$. sarana were recorded in lesser numbers. The former two were recorded only in plot $\mathrm{A}$ while $H$. fossilis was recorded both in plot $A$ and $C$ and $S$. sarana was recorded in plot A,C and D. They were mainly recorded after heavy rain during which water levels were elevated. The majority of fish recorded in Plot B were $P$. reticulata that were able to survive in disturbed conditions. Of the seven species observed at Plot B, only $P$. retciulata was found throughout the year while other fish were recorded only when the water level was high post monsoon. Pseudosphromenus cupanus belonging 
to the family Osphronemidae was only recorded from Plot $C$. This can be attributed to the habitat preference of this species, which includes an abundance of leaf debris, well shaded, with submerged roots and logs (see Pethiyagoda 1991).

Status of Cherry Barb in Mullegama-Habarakada area: Both adults and juveniles of $P$. titteya were recorded from August 2009 to February 2010. Puntius titteya was recorded from three sampling sites (Plots A, C and D). The abundance of adults and juveniles of P.titteya in each sampling site is given in Table 3. Puntius titteya was found mainly under submerged roots and logs, or around leaf debris as in the case of Plots $C$ and $D$, and among overhanging plants of the bank in Plot $A$. The species occupied a level closer to the bottom of the water column in small groups (2-4 individuals), or was seen as solitary individuals near the edge of the stream with intra-specific interactions rarely observed. See Image $2 \mathrm{a}$ and $2 \mathrm{~b}$ for the colour variety of Cherry Barb observed in the study site.

During the months of February and March, the whole stream dried up (Image 1b). After the short drought period which lasted for two months (February 2010 to March 2010), P. titteya was not recorded except

Table 3. Abundance of $P$. titteya in Mullegama-Habarakada.

\begin{tabular}{|l|c|c|c|c|c|c|}
\hline \multirow{2}{*}{ Month and Year } & \multicolumn{2}{|c|}{ Plot A } & \multicolumn{2}{c|}{ Plot C } & \multicolumn{2}{c|}{ Plot D } \\
\cline { 2 - 7 } & A & J & A & J & A & J \\
\hline August 2009 & 7 & 5 & 13 & 4 & 17 & 10 \\
\hline September 2009 & 9 & 5 & 16 & 8 & 14 & 8 \\
\hline October 2009 & 5 & 6 & 12 & 6 & 18 & 9 \\
\hline November 2009 & 11 & 7 & 11 & 5 & 19 & 8 \\
\hline December 2009 & 9 & 5 & 15 & 7 & 14 & 5 \\
\hline January 2010 & 13 & 8 & 12 & 4 & 10 & 7 \\
\hline February 2010 & - & - & 7 & 9 & 6 & 11 \\
\hline March 2010 & - & - & - & - & - & - \\
\hline April 2010 & - & - & - & - & - & - \\
\hline May 2010 & - & - & 1 & - & - & - \\
\hline June 2010 & - & - & - & - & - & - \\
\hline July 2010 & - & - & - & - & - & - \\
\hline August 2010 & - & - & - & - & - & - \\
\hline September 2010 & - & - & - & - & - & - \\
\hline October 2010 & - & - & - & - & - & - \\
\hline November 2010 & - & - & - & - & - & - \\
\hline December 2010 & - & 15 & - & - & - \\
\hline July 2013 & - & - & - & - \\
\hline
\end{tabular}

A - Adults; J - Juveniles once in Plot C during May 2010, when a well grown adult female $P$. titteya was observed. However, following the heavy rains which started from April, the other common species of the stream like $R$. dandia, $D$. malabaricus, Lepidocephalicthys thermalis and $P$. bimaculatus were recorded, but not $P$. titteya.

On a subsequent visit to the area in July 2013, we recorded 15 adults of $P$. titteya (five males and 10 females) in Plot $C$, but were unable to record any individuals from Plot $A$ and $D$ which appeared more disturbed and polluted (especially Plot D). On the positive side, we observed about 20 individuals of adult $P$. titteya in a clean well ( $2.5 \mathrm{~m}$ in length and $\sim 2 \mathrm{~m}$ in depth) which is used for bathing by the villagers, located in between Plot $C$ and $B$ close to the stream ( $3 \mathrm{~m})$ (Image $1 \mathrm{f})$. This well could be a permanent site for $P$. titteya since it does not dry up during the drought periods. In addition to $P$. titteya, two adult $C$. orientalis were also observed from the well.

Threats: The main threats to Plot A were soap water entering from a nearby bathing area, and the slow flow rate of water resulting in the chemicals becoming stagnant. An algal bloom was also observed during the latter part of the study (Image 3d). The bank of the stream in Plot $A$ was undisturbed during the initial days of the study period, but was seen to be disturbed during the latter part as several large trees were cut down, exposing the bottom to sunlight.

Plot B comprised the part of the stream that has been polluted due to human activities including directing wastewater from a nearby human settlement. Though Plot $\mathrm{C}$ was relatively undisturbed, it also faced several anthropogenic threats, the greatest being sand mining (Image 3c). Even in this very small stream, villagers indulged in sand mining and also built several dams along the stream thus reducing the water flow. This resulted in a lowering of depth, as well as the flow rate of Plot $C$ thereby reducing its visibility.

When the survey began, Plot $D$ was one of the most undisturbed habitats (Image $2 \mathrm{c}$ ), but with time it gradually became polluted similar to Plot B (Image $2 \mathrm{~d}$ ). Anthropogenic impacts were the greatest around Plot $D$. Contamination with chemicals washed away from the paddy fields and disposal of household garbage directly into the water were the main threats (Image $3 a, b$ ). Plot $D$ is the best example to demonstrate how a very fragile habitat can change within a short period of time into a barren and polluted one. 


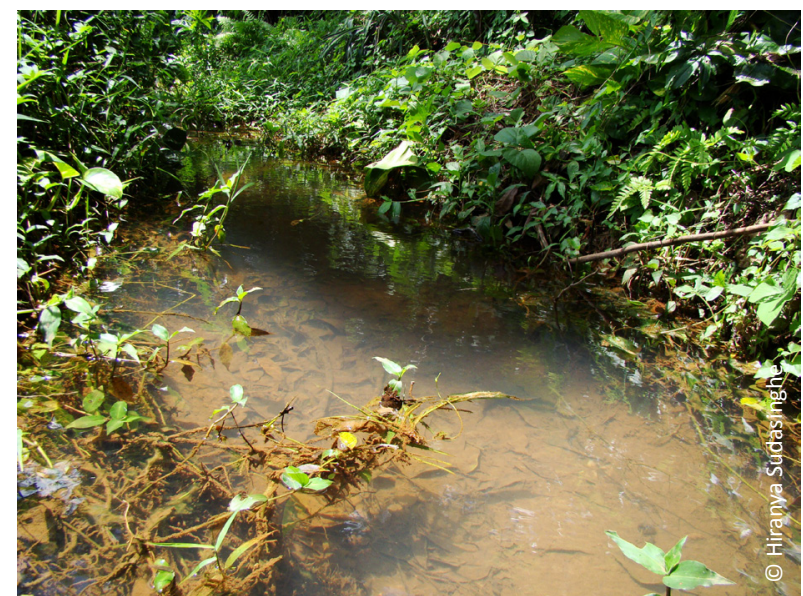

Image 1a. Plot A during the rainy season

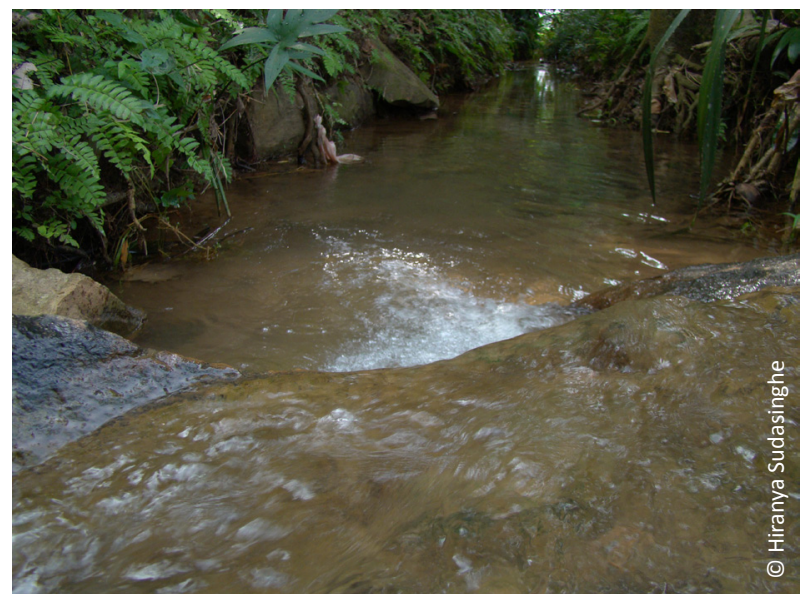

Image 1c. Plot C

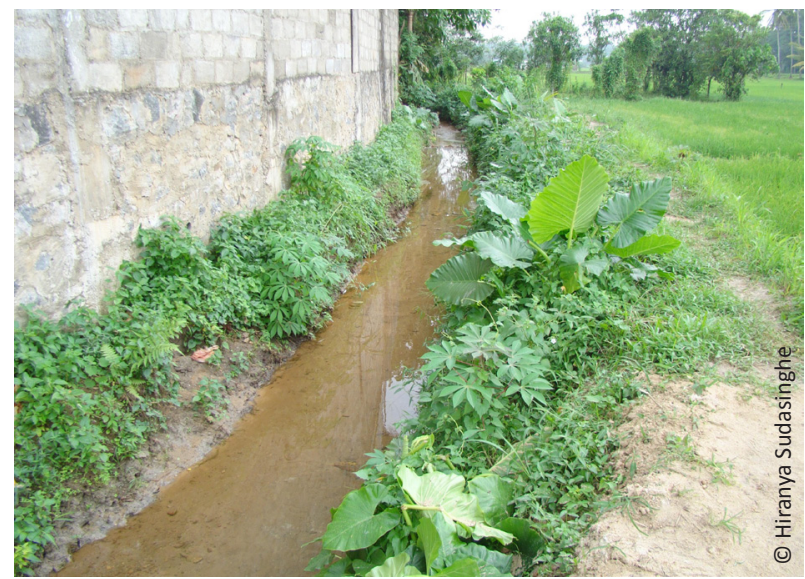

Image 1e. Plot B

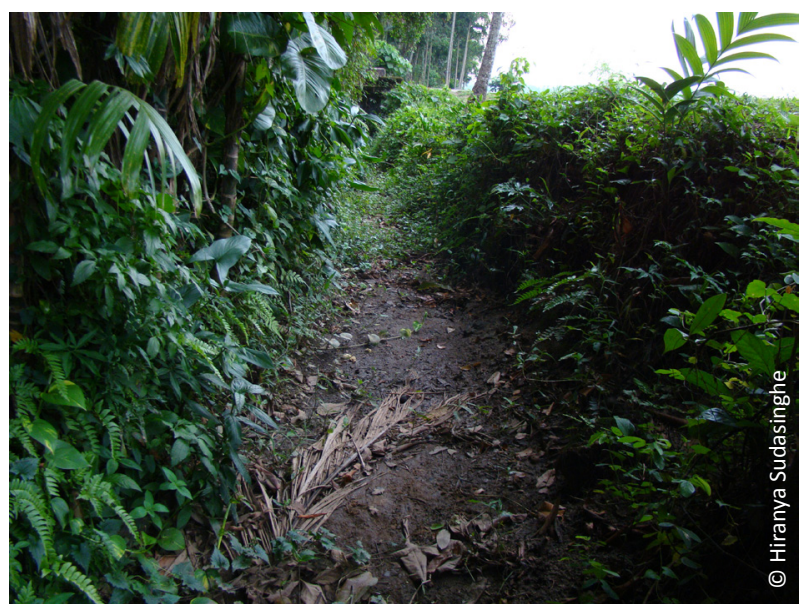

Image 1b. Plot A dried up during the drought period

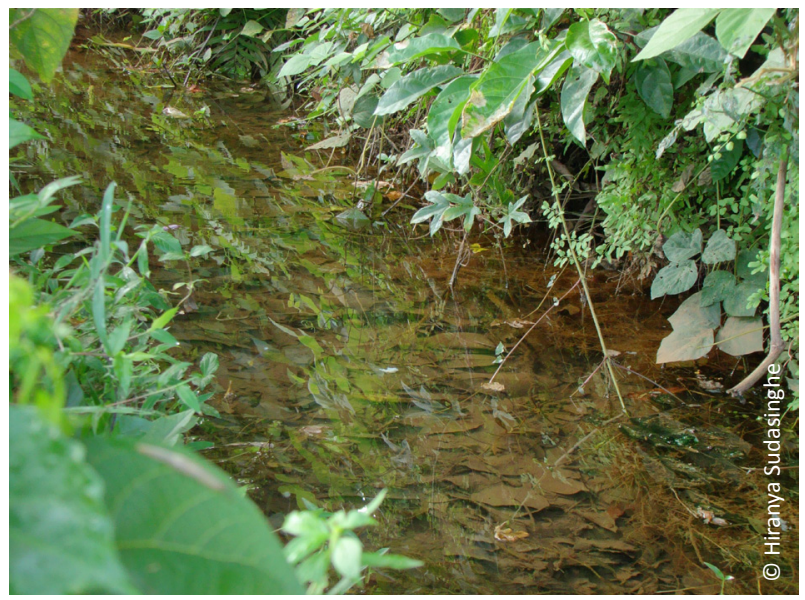

Image $1 \mathrm{~d}$. Plot D during the early stages of study

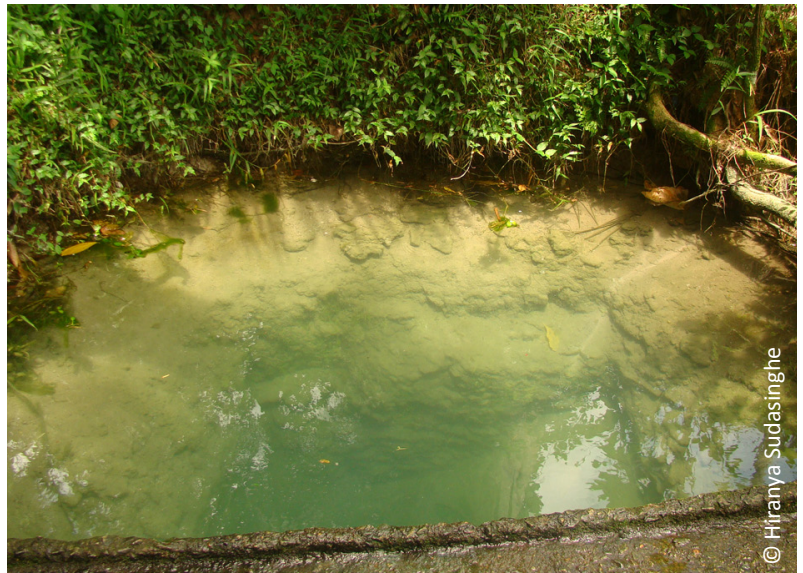

Image 1f. The well in which P.titteya was observed 


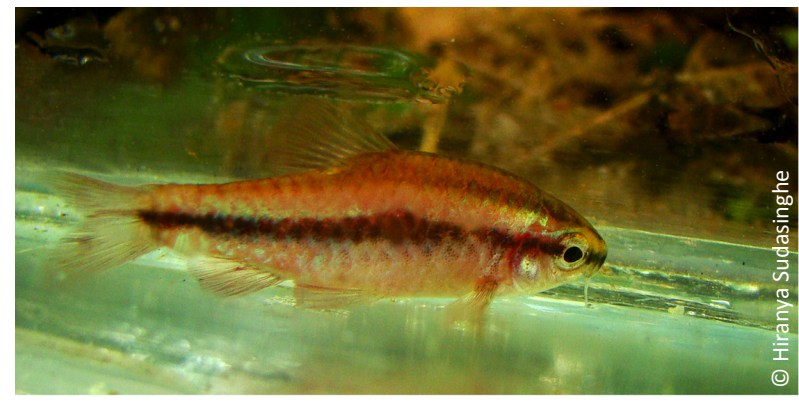

Image 2a. Male P. titteya with neon glow observed at Plot C

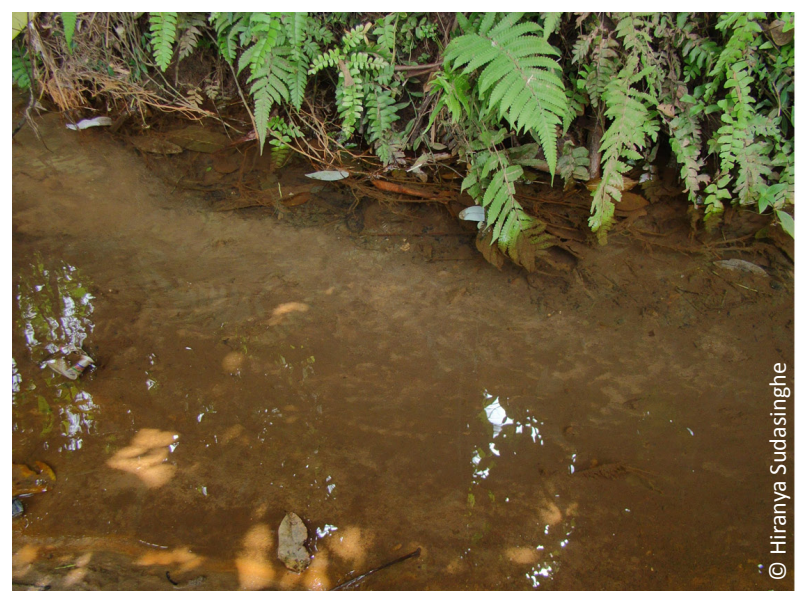

Image 2c. Habitat of P. titteya in Plot D photographed in 2009

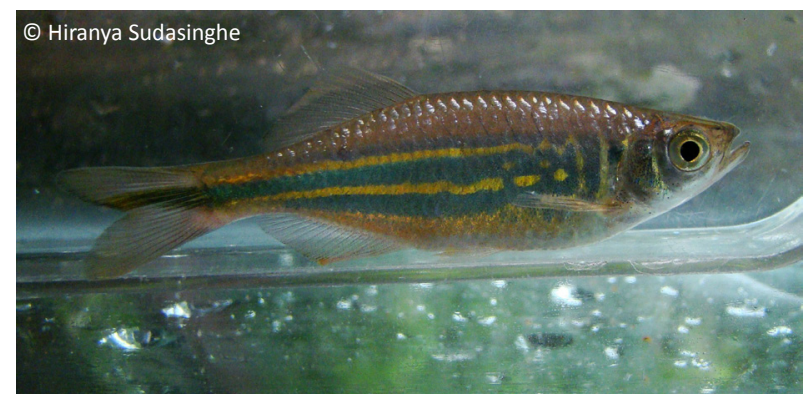

Image 2e. Devario malabaricus observed at Plot C

\section{Discussion}

Though underestimated, small streams like those in Mullegama-Habaraka area are of great importance for endemic aquatic fauna.

Puntius titteya which was categorized as 'Vulnerable' (IUCN Sri Lanka \& MENR 2007) has now been elevated to the status of an 'Endangered' species (MoE 2012). The main threats to the species being overfishing for aquarium trade, pollution of streams and deforestation (Pethiyagoda 1991). At our study sites, the latter two

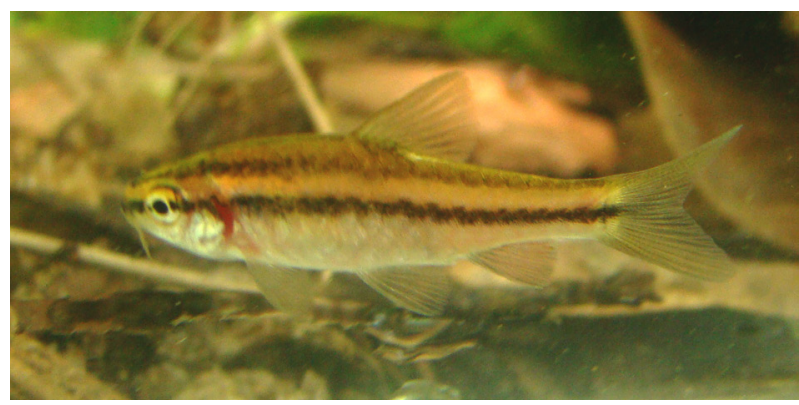

Image 2b. Female $P$. titteya observed at Plot C

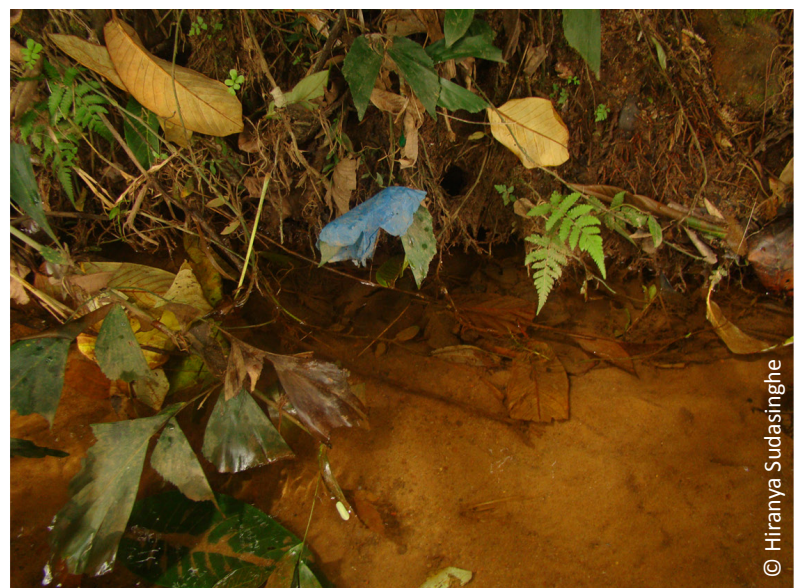

Image $2 \mathrm{~d}$. Habitat of $P$. titteya shown in Image 2 c photographed in 2013

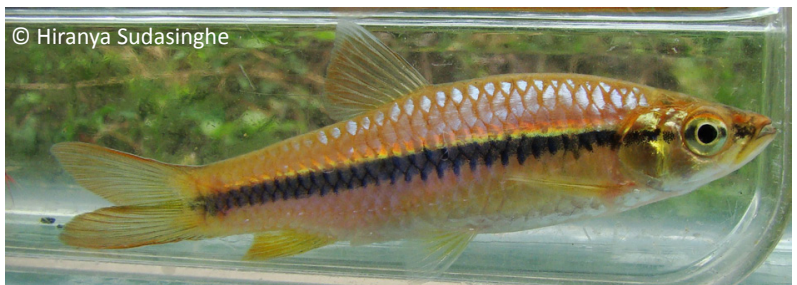

Image 2f. Rasbora dandia observed at Plot C

were observed to be the main threats to the population of $P$. titteya. Mullegama-Habarakada area is one of the closest places to Colombo, where $P$. titteya can be found in the wild. However there is a possibility of extirpation of the species from this region if urgent conservation measures are not taken.

\section{References}

Batuwita, S., M. Silva \& U. Edirisinghe (2013). A review of the danionine genera Rasboroides and Horadandia (Pisces: Cyprinidae), with description of a new species from Sri Lanka. Ichthyological Exploration of Freshwaters 24(2): 121-140.

Deraniyagala, P.E.P. (1929). Two new freshwater fishes. Spoila Zeylanica 15(2): 73-77. 


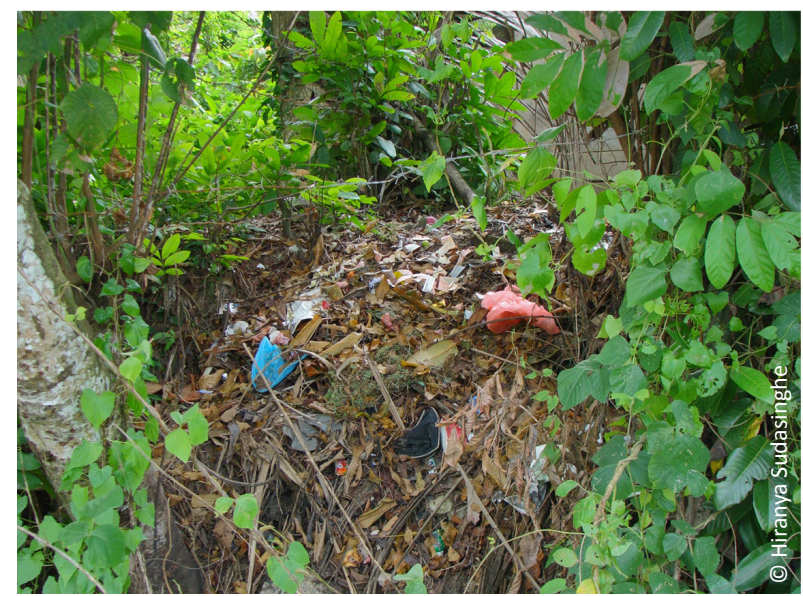

Image 3a. Disposal of garbage at Plot D

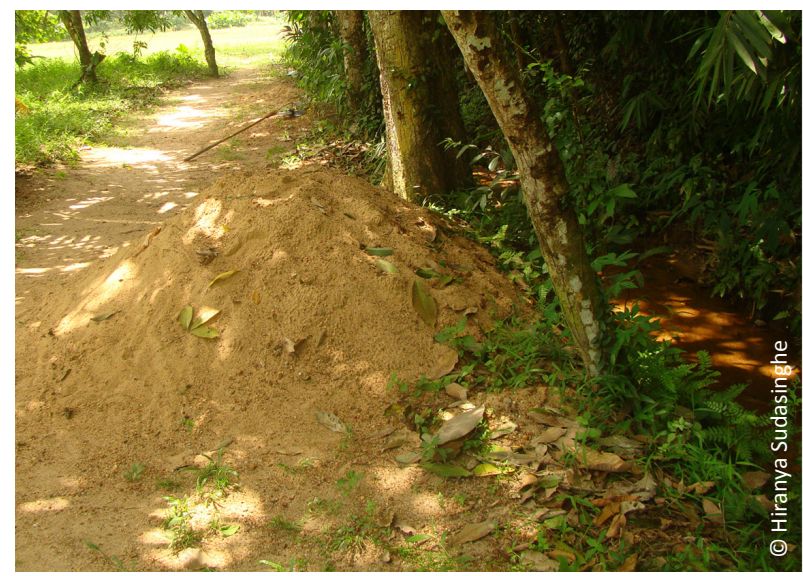

Image 3c. Sand mining at Plot C

Goonatilake, S. de A. (2007). Freshwater Fishes of Sri Lanka. Ministry of Environment, Colombo, Sri Lanka, 162pp.

Goonatilake, S. de A. (2012). The taxonomy and conservation status of the freshwater fishes in Sri Lanka, pp. 77-87. In: Weerakoon, D.K. \& S. Wijesundara (eds.). The National Red List 2012 of Sri Lanka; Conservation Status of the Fauna and Flora. Ministry of Environment, Colombo, Sri Lanka.

IUCN Sri Lanka \& MENR (2007). The 2007 Red List of Threatened Flora and Fauna of Sri Lanka. IUCN Sri Lanka and the Ministry of Environmental and Natural Resources, Colombo, Sri Lanka, 171pp.

Karunarathna, D.M.S.S., A.A.T. Amarasinghe, D.E. Gabadage, M.M. Bahir \& L.E. Harding (2010). Current status of faunal diversity in Bellanwila-Attidiya Sanctuary, Colombo District, Sri Lanka. Taprobanica 2(1): 48-63; http://dx.doi.org/10.4038/tapro. v2i1.2706

Kotalawala, A.B. (1994). Impact of weirs on fish fauna of Wak-Oya, a tributory [sic] of the Kelani River. Journal of the National Science

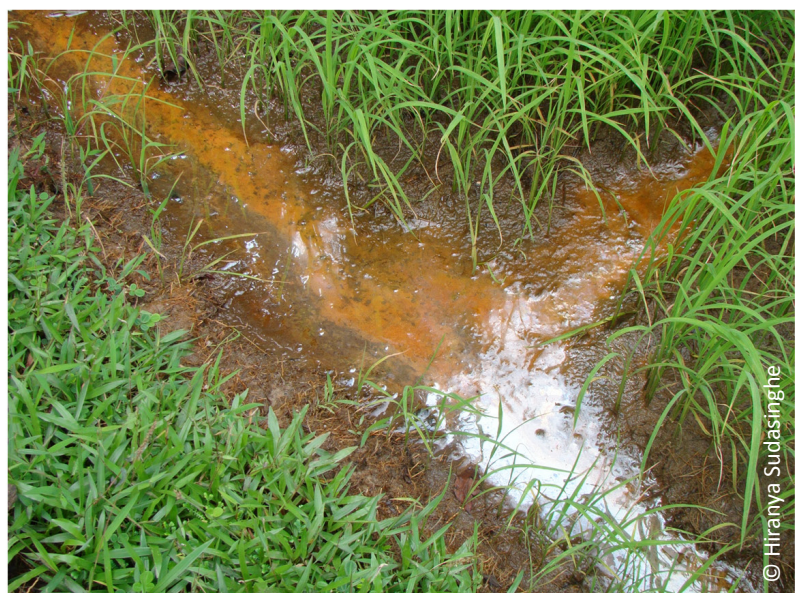

Image $3 \mathrm{~b}$. The agro chemicals used in the paddy fields at Plot D

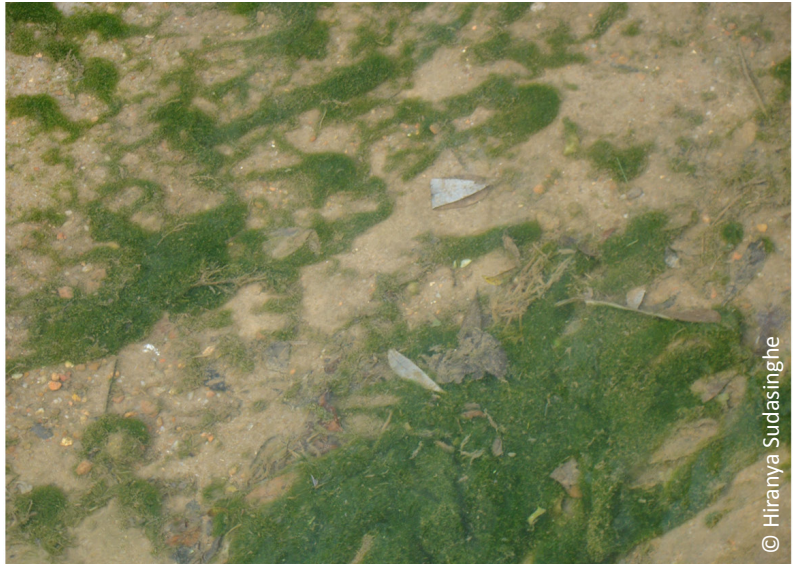

Image 3d. An algal bloom observed at Plot B

Council of Sri Lanka 22(1): 65-86.

MoE (2012). The National Red List 2012 of Sri Lanka; Conservation Status of the Fauna and Flora. Ministry of Environment, Colombo, Sri Lanka, viii+476pp.

Nalinda, M.A.K. (1988). Checklist of the fishes (Pisces) of the Bellanwila-Attidiya marshes, National Zoological Gardens, Sri Lanka. Occasional Papers 3: 1-4.

Pethiyagoda, R. (1991). Freshwater Fishes of Sri Lanka. Wildlife Heritage Trust, Colombo, Sri Lanka, 362pp.

Senanayake, F.R. \& P.B. Moyle (1982). Conservation of freshwater fishes of Sri lanka. Biological Conservation 22(3): 181-195; http:// dx.doi.org/10.1016/0006-3207(82)90068-4

Silva, A., K. Maduwage \& R. Pethiyagoda (2010). A review of the genus Rasbora in Sri Lanka, with description of two new species (Teleostei: Cyprinidae). Ichthyological Exploration of Freshwaters 21(1): 27-50.

Miln 